\title{
The Transmission of the Nigerian Culture Through Education at the Primary School Level, 1960 Till Date
}

\author{
Okediji Hannah Adebola Aderonke \\ Ministry of Education, Oyo State, Nigeria
}

\begin{abstract}
Since Education is the transmission of Culture, the study examined the transmission of the Nigerian culture through Education at the primary school level, since 1960, the year of Nigerian's independence, till date. Historical research method was adopted for the study and data were analyzed using primary sources like; oral interviews and archival materials, while publications like; textbooks, articles in journals, file document, speeches and workshop papers were used as secondary sources. The focuses of the paper are to define culture, analyze the relationship between culture and education, examine the primary school curriculum in Nigeria, trace the transmission processes of the Nigerian culture through primary education, consider few challenges of primary education in the promotion of Nigerian culture and offer suggestions to improve the role of primary education in Nigeria in this regards. The findings revealed that, the western education introduced by the British colonial masters, was patterned after European culture for promotion of their educational philosophies and missionary activities. Subjects like: Latin, English language, Religious studies, simple Arithmetic, artisans and others were included in the earlier curriculum for the benefit of the European economic, social, religious and political ambitions. As Nigerians agitated for independence, unity and freedom, the educational policies began to change to meeting the local needs of Nigerians at all levels of education. The Phelps-Stokes Commission report of 1922 exposed the inadequacies of educational curriculum used in the Nigerian schools, as not meeting the needs of the people. The 1969 Curriculum conference however, brought a complete revolution to the primary school education in the areas of relevance. For instance, subject like: Yoruba, Hausa and Igbo which were major Nigerian languages, Civic Education and Fine Arts were introduced into the primary school curriculum so as to create in-depth awareness for cultural transmission. The roles of such educational bodies like: NERDC and CESAC were fully discussed in the paper. Policies like: Universal Primary Education (UPE) and Universal Basic Education (UBE) introduced in 1976 and 2004 respectively, were efforts of the government at transforming primary education through culture. Challenges like: inadequate funding, personnel problem and implementation problem were indentified. It is therefore recommended that adequate funding be allocated and made available as well as employment of sufficient qualified personnel. There should be strong political will to make policies effective and people's interest should be carried along in policies formulations and implementations.
\end{abstract}

Keywords: transmission, culture, education

\section{Introduction}

Culture is an important aspect of any society; a child is introduced into the culture of his or her society and 
learns it from childhood to the end of life, i.e., from cradle to grave. Therefore, it is believed that without proper knowledge of culture, the task of education cannot be accomplished. It is the culture beliefs, norms, traditions, needs and aspirations of the society that combine to formulate educational policies and eventually the content of the curriculum at all levels of education; from the primary to tertiary level of education in Nigeria.

The Nigerian culture has been transmitted into educational training from birth. Through our traditions and customs and through informal training, children have learnt the culture of respect, hygiene, feeding, dressing, greetings in the indigenous Nigerian languages like; Yoruba, Hausa, Kanuri, Igbo and dialects like; Ekiti, Ijesha, TIV, Fulani, Ijebu, Onko, Egba, Itsekiri and others. Nigerians also learn the cultures of arts, music, aesthetics and help through communal efforts. These various cultural training at the grassroots and home levels brought about harmony, social interaction, unity and joy among various ethnic groups, age grades and peer groups in Nigeria.

These informal trainings however, were modified and inculcated into the primary school education curriculum by the colonial master. But since independence, in October 1st 1960, there had been major changes and transformation which characterize the development and formulation of primary education policy and embedded in the curriculum. At that level, the curriculum's goal was to impart literacy and numeracy, lay a solid foundation for scientific and reflective thinking. There was particular emphasis on Universal Primary Education (UPE). Subjects like: co-curricular activities, creative arts, domestic science and Agriculture, were media of grooming the young minds in their culture.

The focus of this paper therefore, is to define culture, analyze the relationship between culture and education, examine the primary school curriculum since 1960, look into the transmission processes of Nigerian culture through primary education, trace out some of the challenges of promoting the Nigerian culture through education since 1960 and offer some suggestions for the improvement of Nigerian culture through education.

\section{Definition of Culture}

Culture is essential to the existence and civilization of man. It is dynamic and forms the generality of the responses of man to problems of life. It adds value to the social, economic, political and aesthetic needs of the society.

We have material and immaterial, tangible and non-tangible aspects of culture. Material aspects of culture are the values, norms and traditions of the society which can be produced and shared among the people. The immaterial are customs which are of less value and which may not be shared. Tangible are the visible aspects of our culture which are visible and contributing meaningfully to provide economic, political and educational empowerment to the society. Non-tangible are cultures borrowed from other tribes and races, when dropped, they cannot have negative impact on the developmental processes and relationship within the society.

Some of these cultures are aesthetics in nature like: verbal, art, music, dance, bodily decorations, weaving and clothing, dyeing and embroidery, pottery and calabash carving, leatherwork and beadwork, metal work and wood carving.

According to A1/B16 "Yoruba Verbal Arts include praise names, praise poems, tongue twisters, hundreds of prose narratives and riddles as well as thousands of proverbs". The visual arts are: bodily decoration, clothing, pottery, carved calabashes, leatherwork and carved wooden spoons and mirror cases which are available to all who can afford them "of equal importance is hair dress and the cloth headtie by which Yoruba woman are often recognized". 
Below are some of the Nigerian arts and culture used to make life meaningful and for religious, social and economic purposes.

One of the recently carved wooden doors of Idena gate, Afin Ife in Yorubaland.
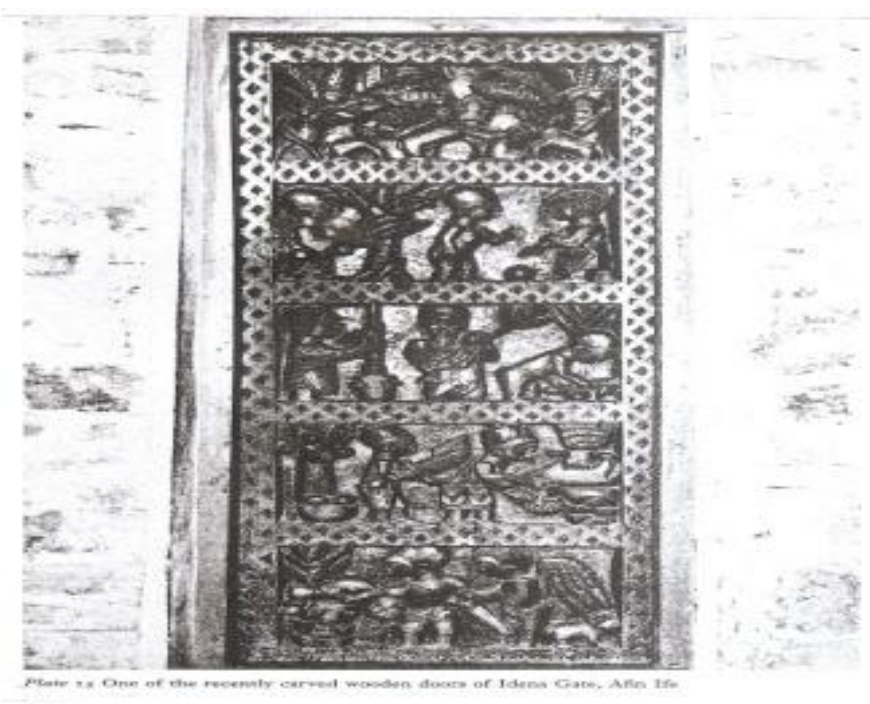

$*$

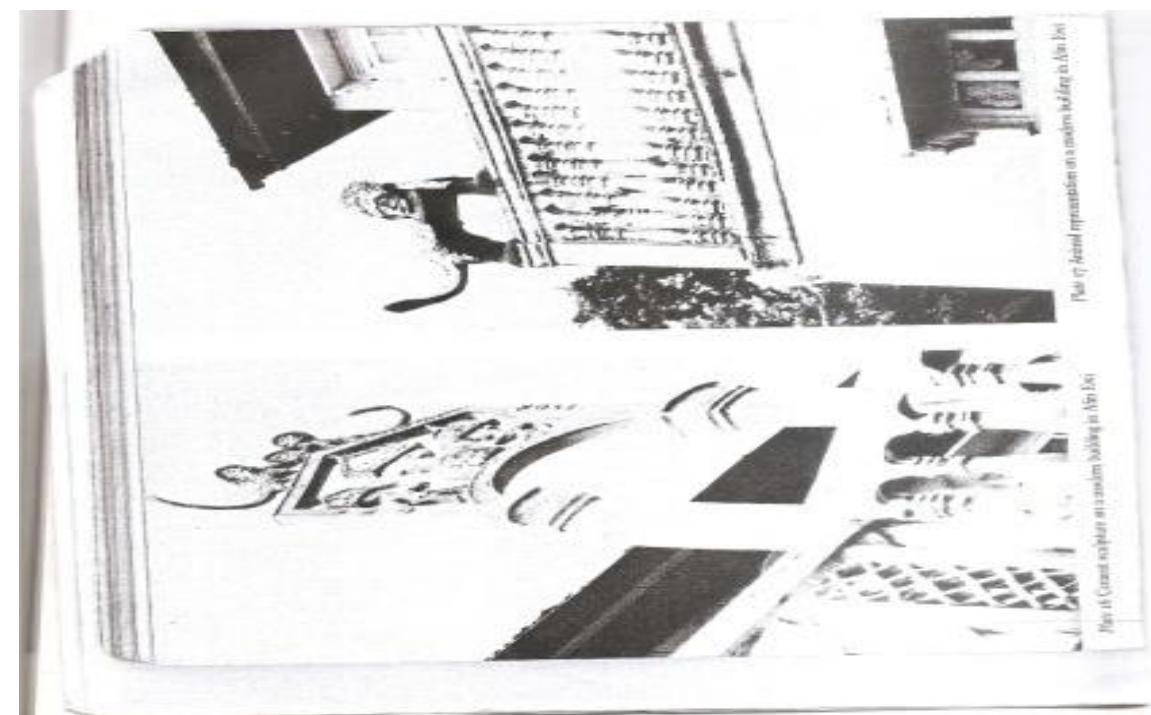

Animal representation on a modern building in Afin Ewi in Yorubaland. Source: National Archives, Ibadan. 
Culture has been said to be the cumulative deposit of knowledge, experience, beliefs, values, attitudes, customs, traditions, religions and notions of man about time. It is the totality of the ethnic background, religious, racial, gender, language and other socio-economic factors and values which sharpens individual lives and upbringing.

Culture has the following characteristics: It could be learnt, transmitted from group or individual to another, assimilated, it uses language as a tool, it is attractive, dynamic and varies from one group of people to another.

Culture is important because it transfers useful values to other people. It can be adopted. It aids social interaction, engenders peace and unity among people of different races, tribes and languages, it specifies language differences, promotes and identifies a people. It is also useful in child bearing, child rearing and family planning.

According to George (2014) in a paper delivered at the World Culture Day (2014) at Ibadan, Nigeria, he defined culture "in the context of the characteristics of a particular group of people, that shared everything history, language, religion, cuisine (food), social habits, music and arts. Culture is a marker of identity; culture is a way of life of a people; culture is everyday life experience. In other words, culture is what we as a people practice, do, experience, believe in, enjoy and benefit from day in, day out. We are never tired of doing it. We can do it again and again. That is our culture. For instance, in Ibadan, music, politics, amala (amala-politics); Oyo, praise singing, local cow milk (WARA), Argungu fishing festival in the North, Adire in Abeokuta and swimming in the riverine areas, to mention a few".

From the above quotation, the author has defined culture in a practical way, relating it to the Nigerian context, ranging from the habits and practices peculiar to the major tribes in the country; i.e. Yoruba, Hausa and the riverine areas (Itsekiri and Igbo) people.

\section{The Relationship Between Culture and Education}

Relationship connotes the connection, interaction and level of closeness that exists between two people or phenomena which make one identify with another or that brings similarities in actions, procedures and habits or behaviors between two things when brought into critical comparison.

Going by sociologists' definition of education, according to Osokoya (1987), education is "the process of cultural transmission and renewal", culture on the other hand is the cumulative deposit of knowledge, experience, beliefs, values, attitudes, customs, traditions, religion and notions of man about time.

From the above definitions, we could observe a deep similarity between culture and education. Education is the way or method of translating culture into practical way of life, while culture forms the background for knowledge, traditions and customs that one inherits from birth. Education serves as the link between people and their culture, values, philosophies, religions, political organizations, science and technology both known an unknown.

Through education which is teaching and learning of divers knowledge and skill; cultural values are transferred, passed on to each succeeding generation and imbibe, emulate as well as improve upon their cultural heritages.

Cultural values are shared and distributed within a society, both among the literate, illiterate and neo-literate for the development of their offspring and society. Going along this line, Archibald Callaway defined culture as "the acquired pattern of life handed on from one generation to another in any particular society". 
In Nigeria, with multi-cultural ethnic groups, our various cultural beliefs are harmonized and integrated into schools.

\section{The Primary School Curriculum in Nigeria, 1960 Till Date}

Prior to 1960, the year of Nigeria independence, Nigeria's educational policy and curriculum had been guided by edicts, ordinances, decrees and laws. The overall objective of education at all levels was tailored after European interest, specifically British government's interest. In the pre-independence years educational law was promoted at regional, state, and central levels backed by government commitment. Therefore in 1955, free primary education was introduced in the former western region, 1957 in the eastern region and in the Lagos territory.

The need for national cohesion, relevance and unity in the education and curriculum brought about the revolution that led to the national conference on curriculum development held in Lagos from 8th to 12th September 1969 sponsored by the Nigerian Educational Research and Development Council (NERDC).

The Curriculum Conference was number one among three conferences organized on curriculum formulation. The conference aimed at reviewing the old and identifying new national goals of education at the primary, secondary and tertiary levels, providing the task to be accomplished and conditions to be fulfilled as touching needs of the various groups in the society and the curriculum substance and contents. The 1969 curriculum conference eventually came out with the recommendation of the 6-3-3-4 system of education. The system implied six years of primary education, three years of junior secondary school, three years of senior secondary school and four years of tertiary institutions. The conference also referred the drafting of the national policy to the federal and the state ministry of education in 1972 which gave birth to the National Council on Education (NCE) which eventually recommended the National Policy on Education (NPE), first published in 1977. The NCE organized a seminar in 1973 to work out the modality for the Nigerian educational curriculum.

Curriculum from primary school level after independence enhances better understanding and development among our children and teaming population so that we are no longer enslaved by the colonial cultural values as an agent of change from European culture to Nigerian culture.

From the foregoing it is clear that education and culture are closely related because, one leads to the promotion, improvement and transfer of the other, from place to place, people to people and generation to generation.

For instance, music albums comprise of well researched and composed songs, poems, folksongs, folktales and traditional philosophical statements useful for entertainments, promotion, preservation and development of the rich culture of Nigerians.

Through informal and formal education, education of our little children and youths are re-orientated in our value systems. These inculcate in them, the culture of recreation, appreciation of nature, respect for traditions, norms and ancient values of the society.

The outcome for the primary education curriculum was as follows:

1. Education given at primary level must be for children between ages six and eleven plus years;

2. Such education must inculcate permanent literacy and numeracy and justify reasons for scientific and reflective thinking;

3. It also recommended universal primary education (UPE) introduced in 1976;

4. It suggested co-curriculum activities for teaching and learning at primary school level. These included creative Arts, Agriculture and Domestic Science; 
5. It recommended a revolution in the teaching methodology. These included exploratory and experimental methods, continuous assessment, counseling services and provision of specialist teachers.

For a proper take-off and implementation strategies for the U.P.E. in 1976, the federal government of Nigeria under General Yakubu Gowon organized various training programmes for the preparations of teachers for primary school pupils from September 1974. Primary schools leavers were admitted for five year teacher's grade two course, those with secondary school certificates did one year programme, those with secondary school certificates who failed, used two years, while those with secondary modern school certificate or S.5 spent three or four years in the secondary school and spent three years to qualify for Teachers grade two certificates. The above explained the more reason most of the primary schools teachers in Nigeria today are qualified teachers.

In 2004, another educational policy was launched to make up for the lapses in the primary and secondary education curriculum. The new system is the Universal Basic Education (U. B. E).

Basic education according to the National Policy on Education as cited by Okediji (2012) is "The education given to children aged 0-15 years. It covers early childhood care and education for ages 0-5 and nine years of formal schooling, consisting of six years of free primary education and three years of junior secondary education. Equally included in the education system are special interventions directed at nomadic and migrant children, mass literacy, adult and non-formal education for those above the formal school age".

The following provision was made for primary school curriculum in the U. B. E, system of education in Nigeria:

1. Six years will be spent in the primary school, which a child will commence at age six;

2. Appropriate level of literacy, numeracy, manipulative, communicative and life skills, ethical, moral and civic values; and

3. Primary education being the foundation level is systematically connected to the junior secondary school.

The current curriculum in Nigeria was introduced in 2013 as 1-9-3-4 curriculum of education. This curriculum is infact the same as 9-3-4 system with addition of one year early childhood education before the primary school level. This curriculum lays emphasis on achieving education for all (E. F. A). An international educational objective/goal launched in the year 2000, to be fully matured or achieved in the year 2020 .

In summary, since 1960 after independence, the Nigerian government had through her education experts changed the National Policy on Education and in effect, the school curriculum from primary level to other levels to achieve improvement on education with a bid to promoting our culture to the same or something close to that of the western world, but the question is, have we been able to accomplish this? No. this is because, each laudable policy or curriculum failed at implementation level. We dwelt much on this and later on the challenges of primary education.

\section{The Transmission Processes of the Nigerian Culture Through Primary Education, 1960 Till Date}

The transmission process is the methodology or the procedures by which communication flows from one person, group of persons, place to place, within and outside a particular environment. Talking of the transmission processes undergone by the culture of Nigerians through primary education, I mean that of the education, curriculum, syllabus and subjects taught at the foundation level of education in Nigeria, primary school has generally been used as medium for inculcating cultural values, norms and local traditions into our children from early stage of their education so as to promote, secure, preserve and proliferate some of the good heritages 
embedded in them. Since 1960 after independence, the Nigerian government and its education experts have seen the need to re-orientate children and youth to imbibe Nigerian local traditions and thus see education as the most effective weapon to accomplish this task. It then became necessary that the curriculum content be packaged to reflect this goal. To accomplish this task, bodies like: Nigerian Educational Research and Development Council (NERDC), Comparative Education Study and Adaptation Centre (CESAC) in collaboration with other governmental and non-governmental agencies, Joint Consultative Committee on Education (JCCE), National council on education (NCE), National Commission for Mass Literacy Adult and Non-Formal Education (NMEC) and Non-Governmental Association for Literacy. Support Services (NOGALSS) have been working assiduously to formulate curriculum capable of transmitting cultural values into the pupils as well as adult learners at elementary level both in formal and non-formal primary school levels.

For instance, music and theatre art are aspects of culture taught in the primary schools, because it is useful for transmitting ideas and aspirations which bring relaxation and enjoyment to young folks. According to Alabi, R. O. (2008) who was a commissioner for education in Oyo state, Nigeria, commenting on an album released by an artist said, "the album is a collection of specially researched and composed songs, poem, folksong, folktales and traditional and entertainment of Odua children in the Yoruba language".

The teaching of Fine Art at the primary school level in Nigeria have strengthened cultural awareness, national unity and developed pupils and adult learners sense of appreciation for local materials and heightened their capacity for production of materials for economic empowerment.

\section{The Role of NERDC and CESAC in the Transmission Processes Through Primary Education Since 1960 Till Date}

The following transmission roles were played by NERDC:

1. Formulation of educational curriculum;

2. Introduction of new subjects like computer studies, creative arts etc. into the primary education curriculum and syllabus;

3. Preparation of instructional materials for the various subjects introduced through the U. B. E policy;

4. NERDC was established by decree 31 of 31st August 1973 and has hitherto played the role of promoting, coordinating, educational research from primary level to tertiary levels; and

5. It also identifies educational problems for research purposes with a view to solving such problems;

6. Maintenance of central register for educational research;

7. Publishing of educational research results and sponsoring of both national and international research conferences. Involved in the formulation of the national policy on education first published in 1977 and reviewed in 1981, 1998, 2004 and 2013;

8. Organizing seminars and workshop for curriculum development materials on subjects like: Igbo, Hausa, Yoruba, French, English language, Art and Crafts, Physical and Health Education and Mathematics.

CESAC was established in 1967 at the University of Lagos to work out a more appropriate system of education which is continually adaptable and responsive to people's economic and social needs. It has conducted educational research seminars to correct the defect of educational curriculum and improvement in subjects related to science and technology and CESAC is involved in the procurement of educational and vocational equipment to schools. 
According to "NERDC at a glance" a publication of the NERDC cited by Okediji (2011), the mandates of the NERDC are as follows:

1. To encourage, promote and co-ordinate all educational research programmes in Nigeria;

2. To identify educational problems in Nigeria where research is needed and the establishment of the order of priority thereof;

3. To encourage research into educational problems and for that purpose to undertake, commission, incorporate and finance such research projects as the council thinks fit;

4. To periodically compile and publish the list of research projects;

5. To compile, publish and sponsor the publication of the results of educational research, particularly in relation to Nigerian education problems and the popularization of anyone that is in the council's opinion of a national importance;

6. To assess, survey or investigate any education matter considered necessary, either independently or in co-operation with individual organization;

7. To identify language problems for the purpose of carrying out research into such problems and finding solutions thereto; and

8. To establish and maintain a research and development library to which new, educational books and other related publications may be disposed.

\section{Book Development}

1. To promote the development of curricula at all levels of educational system;

2. To develop new techniques and approaches to curriculum development;

3. To produce syllabuses and instructional materials;

4. To carry out studies in comparative curriculum; and

5. To develop and encourage the development of materials for various languages taught in schools. 
THE ORGANOGRAM OF NERDC

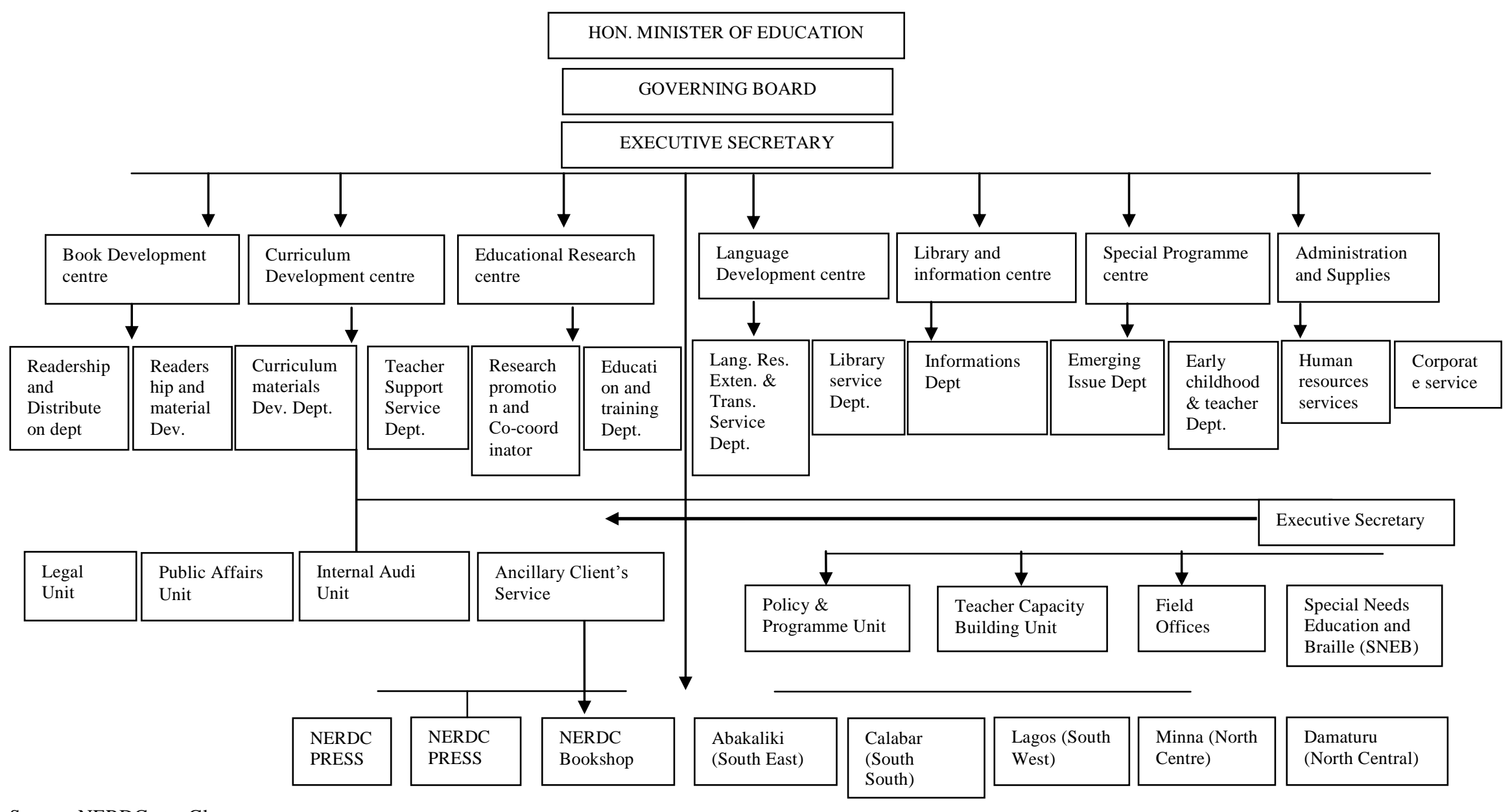

Source: NERDC at a Glance. 
From activities of the federal government and the established bodies like: NERDC, CESAL, NCE, JCCE, NOGALSS and NMEC. The primary education since 1960 has gradually adapted to our local needs and also integrated both the pupils and adult learners into their original culture and traditions.

Challenges of primary education in the promotion of Nigeria culture since 1960 till date.

Challenges are constraints, problems or impediments that stand on the way of progress of any human endeavor, such challenges may be physical or spiritual.

Though the Nigerian government and people have tried over the years to inculcate the disciplines of our cultural heritage and caused our children, youths and adult learners to be knowledgeable and also profitable economically, politically, socially, mentally and physiologically from the rudiments of our tradition and culture, so many things still go wrong at both the planning and implementation stages of the school curriculum at all levels, starting from the elementary stage. Some of the challenges are: inadequate funding, personnel problem, implementation problems, statistical problems, intervention of foreign culture, and inadequate infrastructural facilities.

Inadequate funding: Primary education in Nigeria have suffered a lot at planning and implementation stages because of lack or insufficient fund or mismanagement of the little fund released by the government and as a result of the corrupt practices of the fund handlers. Some pilot and research projects had suffered shipwreck for lack of finance.

The tables below showcase the budgetary allocation for the Oyo State Agency for Adult and Non-Formal Education (OYO, AANFE) for 2014 and 2015 and that of the State Universal Basic Education Commission, (OYO, SUBEBEB) for 2014 and 2015 respectively. These are the bodies responsible for primary education at both formal and non-formal levels in Oyo State, Nigeria.

MINISTRY/PARASTATALS AANFE

AGENCY CODE: AANFE 416/10

ANNEXTURE VI: 2015 OVERHEAD COST 


\begin{tabular}{|c|c|c|c|c|c|c|c|c|c|c|c|c|c|}
\hline $\begin{array}{l}\text { Sub } \\
\text { head }\end{array}$ & Details of expenditure & $\begin{array}{l}\text { Approved estimates } \\
2014\end{array}$ & $\begin{array}{l}\text { Jan. } \\
\text { \# }\end{array}$ & $\begin{array}{l}\text { Feb. } \\
\#\end{array}$ & $\begin{array}{l}\text { Mar. } \\
\#\end{array}$ & $\begin{array}{l}\text { April } \\
\#\end{array}$ & $\begin{array}{l}\text { May } \\
\#\end{array}$ & $\begin{array}{l}\text { June } \\
\#\end{array}$ & $\begin{array}{l}\text { July } \\
\#\end{array}$ & $\begin{array}{l}\text { Aug. } \\
\#\end{array}$ & $\begin{array}{l}\text { Total } \\
\#\end{array}$ & $\begin{array}{l}\% \\
\text { Performance }\end{array}$ & $\begin{array}{l}2015 \\
\text { proposed } \\
\text { estimate }\end{array}$ \\
\hline 2 & $\begin{array}{l}\text { Travel, transport and leave } \\
\text { bonus }\end{array}$ & $300,000.00$ & - & - & - & - & - & - & - & - & - & & $300,000.00$ \\
\hline 3 & Utilities & - & - & - & - & - & - & - & - & - & - & & - \\
\hline 4 & Telephone service & - & - & - & - & - & - & - & - & - & - & & - \\
\hline 5 & Stationery & $500,000.00$ & - & - & - & - & - & - & - & - & $400,000.00$ & & $500,000.00$ \\
\hline 6 & $\begin{array}{l}\text { Maintenance of office } \\
\text { furniture \& equipment }\end{array}$ & $200,000.00$ & - & - & - & - & - & - & - & - & - & & $200,000.00$ \\
\hline 7 & $\begin{array}{l}\text { Maintenance of vehicles } \\
\text { and capital assets }\end{array}$ & $250,000.00$ & - & - & - & - & - & - & - & - & - & & $250,000.00$ \\
\hline 8 & Consultancy service & - & - & - & - & - & - & - & - & - & - & & - \\
\hline 9 & Grants and contributions & - & - & - & - & - & - & - & - & - & - & & - \\
\hline 10 & $\begin{array}{l}\text { Training and staff } \\
\text { development. }\end{array}$ & $5,000,000.00$ & - & - & - & - & - & - & - & - & $352,000.00$ & & $5,000,000.00$ \\
\hline 11 & $\begin{array}{l}\text { Entertainment and } \\
\text { hospitality }\end{array}$ & $250,000.00$ & - & - & - & - & - & - & - & - & - & & $200,000.00$ \\
\hline \multirow[t]{15}{*}{12} & Miscellaneaous & & & & & & & & & & - & & \\
\hline & Running grants & $2,000,000.00$ & - & - & - & - & - & - & - & - & $540,000.00$ & & $2,000,000.00$ \\
\hline & Monitoring & $1,500,000.00$ & - & - & - & - & - & - & - & - & $450,500.00$ & & $1,500,000.00$ \\
\hline & Publicity & $2,000,000.00$ & - & - & - & - & - & - & - & - & $588,500.00$ & & $2,000,000.00$ \\
\hline & International Lit. day & $10,000,000.00$ & - & - & - & - & - & - & - & - & - & & $2,000,000.00$ \\
\hline & Literacy by radio & $10,000,000.00$ & - & - & - & - & - & - & - & - & - & & $10,000,000.00$ \\
\hline & Adult literacy on T.V. & - & - & - & - & - & - & - & - & - & - & & - \\
\hline & $\begin{array}{l}\text { Payment of honouraria to } \\
\text { facilitators of AANFE } \\
\text { learning centres. }\end{array}$ & $4,500,000.00$ & - & - & - & - & - & - & - & - & - & & $4,500,000.00$ \\
\hline & Beam publicity & - & - & - & - & - & - & - & - & - & - & & - \\
\hline & $\begin{array}{l}\text { NMEC, JCCE \& NCE } \\
\text { meeting }\end{array}$ & $2,000,000.00$ & - & - & - & - & - & - & - & - & - & & $2,000,000.00$ \\
\hline & $\begin{array}{l}\text { Conduct of end of session } \\
\text { xmas }\end{array}$ & $500,000.00$ & - & - & - & - & - & - & - & - & - & & $500,000.00$ \\
\hline & $\begin{array}{l}\text { Night and overtime } \\
\text { allowance drives }\end{array}$ & $50,000.00$ & - & - & - & - & - & - & - & - & - & & $50,000.00$ \\
\hline & $\begin{array}{l}\text { Printing of literacy } \\
\text { certificates }\end{array}$ & - & - & - & - & - & - & - & - & - & - & & - \\
\hline & Networking/PPP initiative & - & - & - & - & - & - & - & - & - & - & & - \\
\hline & Total & $350,050,000.00$ & - & - & - & - & - & - & - & Nil & $2,330,500.00$ & & $27,000,000.00$ \\
\hline
\end{tabular}


OYO STATE OF NIGERIA ETIMATES, 2014

SUMMARY OF OVER-HEAD COST

HEAD 416/6-OYO STATE UNIVERSAL BASIC EDUCATION BOARDS (SUBEB)

\begin{tabular}{|c|c|}
\hline Details of expenditure & roved estimates 2014 \\
\hline 1. Travels, transport and leave bonus & $26,200,000.00$ \\
\hline 2. Utility service (PHCN) & $2,360,000.00$ \\
\hline 3. Telephone \& postal services & $500,000.00$ \\
\hline 4. Stationary & $3,000,000.00$ \\
\hline 5. Maintenance of office furniture $\&$ equipment & $2,500,000.00$ \\
\hline 6. Maintenance of vehicle \& capital assets & $4,000,000.00$ \\
\hline 7.Consultancy services & $2,000,000.00$ \\
\hline 8. Grants, contribution \& subvention & \\
\hline 9. Training and staff development & \\
\hline a) Policy makers & $25,000,000.00$ \\
\hline b) Staff & $00,000.00$ \\
\hline c) Nomadic and special education teachers & $0,000.00$ \\
\hline d) JCCE & $0,000.00$ \\
\hline e) NCE & $0,000,00$ \\
\hline f) Capacity building for teachers & $51,000,000.00$ \\
\hline g) Capacity building for ECCDE trs. & $11,000,000.00$ \\
\hline 10. Entertainment and hospitality & $1,500,000.00$ \\
\hline 11. Miscellaneous expenses & \\
\hline I. Games and sports & $0,000.00$ \\
\hline II. HIV/AIDS (Advocacy Camp Empowerment) & $2,000,000.00$ \\
\hline III. Judgment Debt & $00,000.00$ \\
\hline $\begin{array}{l}\text { IV. Conduct of state wide school census \& } 4,000,000 \\
\text { Processing of census data. }\end{array}$ & \\
\hline V. Acquisition of internet facilities in all33LGUBEA & $1,000,000.00$ \\
\hline VI. Jet competition & $0,000.00$ \\
\hline VII. Inter-school debates \& quiz competition & $2,500,000.00$ \\
\hline VIII. Running cost to LGEA & $15,840,000.00$ \\
\hline IX. Running cost to school & $24,000,000.00$ \\
\hline X. Home grown school feeding programme & $1,500,000.00$ \\
\hline XI. Instructional materials & $100,000,000.00$ \\
\hline XII. Conduct of promotion examination & $6,000,000.00$ \\
\hline XIII. Federal teachers scheme participants (FTS) & $1,000,000.00$ \\
\hline XIV. Monitoring of field staff in LGUBEAs & $1,000,000.00$ \\
\hline XV. Teachers supervision allowance & $10,600,000.00$ \\
\hline XVI. Publicity and enlightenment & $1,000,000.00$ \\
\hline XVII.Stu. Tut. Ment. Ev. \& Counselling (STUMENC & $1,000,000.00$ \\
\hline XVIII. Printing of forms (insterstate and inter Local) & $1,000,000.00$ \\
\hline XIX. School based management committee matters & $4,000,000.00$ \\
\hline Sub-total 362,500 & 00.00 \\
\hline
\end{tabular}

Source: SUBEB, OYO STATE. 
AGENCY CODE........ 4160006

MINISTRIES/PARASTATALS..SUBE SECTOR... EDUCATION........

\begin{tabular}{|c|c|c|c|c|}
\hline Sub head & Details of expenditure & Actual-2014 & Proposed-2015 & Remark \\
\hline 1 & Travels, Transport and Leave Bonus & $22,241,063.46$ & $26,200,000.00$ & \\
\hline 2 & Utility & $1,745,100.00$ & $1,800,000.00$ & \\
\hline 3 & Stationery & $1,744,500.00$ & $2,200,000.00$ & \\
\hline 4 & Maintenance of Office Furniture and Equipment & $1,438,250.00$ & $2,500,000.00$ & \\
\hline 5 & Maintenance of Motor Vehicles and Capital Assets & $1,344,499.00$ & $4,000,000.00$ & \\
\hline 6 & Consultancy Service & $807,500.00$ & $2,000,000.00$ & \\
\hline 7 & Grants, Contributions and & NIL & NIL & \\
\hline 8 & Training and Staff Development & & & \\
\hline 9 & Policy Makers & $9,000,000.00$ & $10,000,000.00$ & \\
\hline 10 & Staff & $10,000,000.00$ & $12,500,000.00$ & \\
\hline 11 & Entertainment and Hospitality & $1,524,200.00$ & $1,500,000.00$ & \\
\hline 12 & Miscellaneous & & & \\
\hline \multirow[t]{28}{*}{ I } & Nomadic an Special Education Teachers & & $2,000,000.00$ & \\
\hline & JCCE & & $2,000,000.00$ & \\
\hline & NCE & & $1,000,000.00$ & \\
\hline & Capacity building for Teacher & & $35,000,000.00$ & \\
\hline & Games and Sports & $4,750,000.00$ & $4,750,000.00$ & \\
\hline & Medical Bills & & $1,000,000.00$ & \\
\hline & $\begin{array}{l}\text { HIV/AIDS (Implementation of Family Life in Education } \\
\text { Curriculum at Basic School) }\end{array}$ & $948,000.00$ & $2,000,000.00$ & \\
\hline & $\begin{array}{l}\text { Conduct of State wide School Census \& Processing of Census } \\
\text { data }\end{array}$ & & $5,110,000.00$ & \\
\hline & Acquisition of Internet facilities in all 33 LGUBEAs & NIL & $1,000,000.00$ & \\
\hline & Audit Fees (To be sourced from Consultancy SubHead) & & & \\
\hline & Jet Competition & $685,100.00$ & $3,000,000.00$ & \\
\hline & Inter-school Debate \& Quiz Competition & & $3,000,000.00$ & \\
\hline & Legal Matters & & $2,000,000.00$ & \\
\hline & Judgment Debt & & $8,000,000.00$ & \\
\hline & Running Cost to LGUBEA & $14,850,000.00$ & $15,840,000.00$ & \\
\hline & Running Cost to Schools & & $30,000,000.00$ & \\
\hline & Home Grown School Feeding Programme & & $2,000,000.00$ & \\
\hline & Instructional Materials & $35,593,012.00$ & $80,000,000.00$ & \\
\hline & Conduct of Promotion for Teaching \& Non-Teaching Staff & $285,000.00$ & $7,000,000.00$ & \\
\hline & Federal Teacher’ Scheme Participants (FTS) & & $1,000,000.00$ & \\
\hline & Monitoring of Field Staff in LGUBEAs & & $1,000,000.00$ & \\
\hline & Teacher Supervisors' Allowance at 2,000 per month x 12 × 582) & $998,200.00$ & $10,600,000.00$ & \\
\hline & Conduct of Pupils' Promotion Examination & NIL & NIL & \\
\hline & Publicity and Enlightment & & $2,000,000.00$ & \\
\hline & Stu. Tut. Ment. Ev. \& Counseling (STUMEC & & $2,000,000.00$ & \\
\hline & Printing of forms (Insterstate and Inter - Local Transfer form. & & $1,000,000.00$ & \\
\hline & SBMC & & $5,000,000.00$ & \\
\hline & Total & $108,354,453.46$ & $290,000,000.000$ & \\
\hline
\end{tabular}

Source: AANFE, OYO STATE.

From the two tables above, one could deduce that, fund allocations were not regular while certain items were not given any vote at all. From the various allocations, only a fragment is released for specific purposes. 
Personnel problems: Despite the professionalization of teaching profession in Nigeria of today, many unqualified hands are still teaching in the primary schools, most especially in the private, Nursery and Primary schools. There are shortages of teachers and staffs assisting in the public primary schools, private schools, conventional schools and non-formal learning centres.

Statistical problem: Statistical data are not available for the purpose of curriculum planning and implementations. Where data are available in most cases ICT facilities are not available for proper documentation and storage.

Influx of foreign culture: The European culture has culminated major hindrance to the acceptance, promotion and preservation of Nigerian culture among youths and children especially. The culture of the English, imbibed from the colonial masters are still much around and have influenced our education so much that, the teaching of Nigerian culture is not completely absorbed by the pupils. Also, the use of internet facilities and other electronics have influenced the promotion of foreign culture with negative impact on the preservation of our rich culture, because our youth use these electronics for negative purposes to corrupt the society.

Lack of proper national unity and philosophy: The national curriculum formulators i.e. NERDC and CESAC are still finding it difficult to integrate every culture into the educational policy and curriculum because of the multi-cultural nature of our society. For instance, while primary education lasted for six years in the western and eastern part of the country, seven years is used in the northern part of the country.

Insufficient modern communication equipment and good transportation system: Some of the modern equipment and materials like: eligible camera, non-linear machines, radio, computer system etc. which can make cultural transmission easy are not available. Where available, they are not in sufficient quantity. Transportation facilities like: good roads, vehicles and professional drivers are not available for proper mobility of people, goods and services.

Mixing culture with Religion: In Nigeria, there is erroneous ideas that our cultural practices are fetish. While some culture displays attract evil power and negative covenants, there are still godly heritages worthy of emulation and which are quite educative.

Pick and drop policy: The federal government and NERDC are not patient enough for a particular policy to be implemented to fruition before another policy is enforced i.e. 6-3-3-4 system was prematurely implemented before 9-3-4 was introduced.

Low learning achievement: learning achievements are still low compared to what it should be at the primary school level.

Discrimination and access problem: Discrimination among gender, ethnic group, religious, states, local governments, the poor and rich, rural and urban areas are still more visible in gaining access to primary school education in Nigeria.

Policy Issue: the issue of enacting appropriate law and policy on gender issues has not been given proper attention in education.

Finally, if the government and practitioners could pay particular attention to the above, primary education would yield bountiful fruits by promoting our culture. 


\section{Conclusion}

This paper has been able to expose the danger in relying solely on the foreign culture to develop and build a nation and revealed the need for Nigerians to educate their wards at the primary school level, by introducing them to their original culture early and by encouraging them to speak in local languages in order to get used to, promote and preserve their good heritage. It has showcased the primary school curriculum, stage by stage since independence and heightened few of the challenges which had hampered the realization of the vision. Finally, if government and all stakeholders could address these obstacles and manage them well, very soon the culture of Nigerians will be embraced and become a point of attraction to the world.

\section{Recommendations}

The following recommendations are made for this paper:

There is the need to encourage, teach and create activities which can lead to rejuvenation, promotion, preservation and development of our culture among children and youths in our various institutions of learning, right from the primary school level;

Government and individuals, should organize programmes aimed at showcasing the dynamism in our arts and culture and tourism potentials available within Nigeria;

Tours/excursions should be arranged regularly for our pupils in primary schools to expose them to game, traditional event centres and locations dispersed all over the country in order to expose them to their cultural heritages and socio-economic as well as political benefits embedded in their society;

Government should not pay lip-service to the teaching of music and creative arts included in the educational curriculum, rather, professional teachers of the subjects should be made available to take the pupils and the students;

Parents should teach their children at home about Nigerian culture, traditions, norms, ethics and moral uprightness in order to have a sense of identity with their first environment an uphold the future legacy of the unborn generation.

NERDC, CESAC and other curriculum planners should endeavour to integrate, some of the good culture and ingredients of the past government, be it pre-colonial, colonial or post-colonial into the primary education curriculum; and

Nigeria with about 354 multi-cultural ethnic groups should adopt participatory methods, that is, ability to incorporate experts from various ethnic groups and other stakeholders in policy formulation.

\section{References}

Alabi, R. O. (2008). An address delivered by the commissioner for information, Culture and Tourism at the launching of an album titled "Odua children. Com" on Thursday, 27th March, 2008 at the swimming pool area, Premier Hotel, Ibadan. pp. 1-6.

Education and Culture. (2014). Internet http://www.Ask.com/web-answer/society/other/how, http://www.Echow.com/fact 7438904, pp. 1-3.

Fabunmi, M. (2005). Historical Analysis of Educational policy. Formulation in Nigeria; Implications for Educational Planning and Policy. Available on Internet International Journal of African, American Studies, 4(2), 1-6.

George, K. (2014). Cultural entrepreneur development in Nigeria, a paper presented at the world culture day on the 21 st may, 2014 at the Oyo State Council for Arts and Culture, Culture Centre, Mokola Ibadan. pp, 1-5. 
Kolawole. (2006). Curriculum design "implement \& innovate” Ibadan Culture Studies Group (ISCG) Faculty of Arts, University of Ibadan, Ibadan, Nigeria. pp. 1-11, 44-59, 111.

National Archives, Ibadan (NAI). Yoruba palaces: A study of Afins of Yoruba land (A1/06) by oyo, G. J. (1966). London: University of London Press Ltd., pp. 75-81.

Obafemi, O., \& Ayakoroma. (2011). Perspectives on Cultural Administration in Nigeria Kraft Books Limited, Ibadan, pp. 1-30.

Okediji, H. A. A. (2011). The Role of the Nigerian Educational Research and Development Council (NERDC) in the formulation of education policy in Nigeria. KIU Journal of Education, 4, 99-105.

Okediji, H. A. A. (2012). The challenges of planning and implementing the 9 years basic education curriculum in Nigeria. African Journal of Historical Sciences in Education, 8(1), 101-109.

Osokoya, I. O. (2014). 6-3-3-4 education in Nigeria history strategies issues of the educational publisher Ltd., Agbowo Express, Ibadan. pp, 1-55.

Oyewo, O. O. (2013). Promotion, development, presentation and marketing of our Arts and culture being a paper deliver at the world culture day on 21st May 2013, at the Oyo state council for Arts and Culture Centre, Mokola, Ibadan. pp, 1-55. 